\title{
Processing of Corn Cobs Waste into Briquettes Using Cob Press Machine Capacity 40 kg / hour
}

\section{Pengolahan Limbah Tongkol Jagung menjadi Briket Menggunakan Mesin Press Tongkol Kapasitas 40 kg/jam}

\author{
Yasinta Sindy Pramesti ${ }^{1}$, Bambang Kristanto ${ }^{2}$, Heru Pratama $^{3}$ \\ [yasintasindy@gmail.com ${ }^{1}$ ]
}

Program Studi Teknik Mesin, Universitas Nusantara PGRI Kediri ${ }^{1,2,3}$

\begin{abstract}
Along with economic growth and population growth, it will continue to increase, it will lead to an increase in energy consumption in all sectors of life. Indonesia is known as an agricultural country, where most of its territory is in the form of wide and fertile agricultural lands with the majority of the population as farmers. One of the wastes generated from the agricultural sector is corn cobs. The large amount of corn cobs waste produced by farmers in the Ngunut District of Tulungagung Regency is a loss if it is not converted to something more efficient and useful. This study aims to design a tool that can convert corn cobs waste into briquettes. Based on the results of research that has been done, the corncob charcoal press machine that is made has a capacity of $40 \mathrm{~kg} / \mathrm{hour}$. This machine has a bore diameter of $35 \mathrm{~mm}$ and a bore depth of $17 \mathrm{~mm}$. The resulting roll rotation speed reaches $4.15 \mathrm{rpm}$.
\end{abstract}

Keywords - briquettes; convertible; waste; corn cobs

Abstrak. Seiring dengan pertumbuhan ekonomi dan pertambahan penduduk terus meningkat akan menyebabkan peningkatan konsumsi energi di segala sector kehidupan. Indonesia yang dikenal sebagai negara agraris yang sebagian besar wilayahnya berupa lahan pertanian yang luas dan subur dengan mayoritas mata pencaharian penduduknya sebagai petani. Salah satu limbah yang dihasilkan dari sector pertanian adalah limbah tongkol jagung. Banyaknya limbah tongkol jagung yang dihasilkan petani di kawasan Kecamatan Ngunut Kabupaten Tulungagung merupakan suatu kerugian apabila tidak di konversikan kepada hal yang lebih efisien dan berguna. Penelitian ini bertujuan untuk merancang suatu alat yang dapat mengkonversikan limbah tongkol jagung menjadi briket. Berdasarkan hasil penelitian yang telah dilakukan, mesin press arang tongkol jagung yan dibuat memiliki kapasitas $40 \mathrm{~kg} / \mathrm{jam}$. Mesin ini memiliki diameter lubang pencetak $35 \mathrm{~mm}$ dan kedalaman lubang pencetak $17 \mathrm{~mm}$. Kecepatan putaran roll yang dihasilkan mencapai 4,15 rpm.

Kata Kunci-briket; konversi; limbah; tongkol jagung

\section{Pendahuluan}

Sumber energi yang tidak dapat diperbarui khususnya fosil mempunyai peranan penting dalam kehidupan manusia sehari-hari. Seiring dengan bertumbuhnya perekonomian dan pertambahan penduduk yang terus meningkat di Indonesia, menyebabkan pertambahan konsumsi energi di segala sektor kehidupan. Energi fosil merupakan sumber energi yang tidak dapat diperbaharui, untuk itu perlu dicari energi terbarukan agar tidak tergantung pada bahan bakar . Salah satu energi terbarukan yang mempunyai potensi besar di Indonesia adalah biomassa. Biomassa adalah istilah untuk semua jenis material organik yang dihasilkan dari proses fotosintesis seperti : daun, ranting, rumput, gulma, gambut, limbah pertanian dan kehutanan. Biomassa dapat dimanfaatkan sebagai bahan bakar alternatif dengan berbagai macam proses seperti anaerobic digestion, gasifikasi, pirolisa, pembuatan briket maupun dibakar secara langsung [1]

Indonesia yang dikenal sebagai negara agraris yang sebagian besar wilayahnya berupa lahan pertanian yang luas dan subur dengan mayoritas mata pencaharian penduduknya sebagai petani. Adapun limbah pertanian yang banyak terdapat dilingkungan sekitar kita yaitu limbah tongkol jagung [2].Berdasarkan produksi jagung maka dihasilkan lebih kurang 30\% tongkol jagung. Nilai Residue to Product Ratio (RPR) tongkol jagung adalah 0,273 pada kadar air 7,53\% [3]. Banyaknya limbah tongkol jagung yang dihasilkan petani merupakan suatu kerugian apabila tidak di konversikan kepada hal yang lebih berguna.

Beberapa hasil penelitian menunjukkan bahwa limbah tongkol dapat dikonversikan menjadi bahan bakar alternatif. Hasil potensi produksi limbah untuk pemanfaatan limbah tongkol sebagai bahan bakar alternatif melalui proses gasifikasi menghasilkan gas sebesar 92,852 ton [1]Berdasarkan potensi material tongkol jagung di Kabupaten Solok sebanyak 3.586 ton per tahun dihasilkan tongkol jagung 30\%. Kebutuhan tanah untuk produksi batu bata saat ini $26.090 \mathrm{~m}^{3}$ per tahun dan membutuhkan substitusi serat tongkol jagung sebanyak $8.838 \mathrm{~kg}$. hal ini akan mencukupi apabila digunakan sebagai bahan substitusi pada pembuatan batu bata komposit dan akhirnya bisa menurunkan jumlah pemakaian tanah lempung sebagai bahan utama pembuatan batu bata di Nagari Aripan [4]Upaya yang dapat dilakukan adalah mengolah limbah pertanian khususnya tongkol jagung kering untuk dapat digiling menjadi serbuk tongkol 
jagung. Selanjutnya serbuk tongkol jagung tersebut akan diolah lebih lanjut untuk meningkatkan kadar protein dan lainnya, sehingga sesuai dan membantu mengatasi kelangkaan pakan di musim kemarau/paceklik. Penerapan teknologi tepat guna berupa mesin hammer mill dapat membantu kalangan peternak untuk mengolah tongkol jagung menjadi serbuk tongkol jagung dengan kapasitas produksi $100 \mathrm{~kg} / \mathrm{jam}$ [5].

Dengan adanya mesin pengolah tongkol jagung dimaksudkan dapat mengolah tongkol jagung menjadi lebih bermanfaat dan mempunyai nilai jual. Briket tongkol jagung adalah hasil pembakaran dari tongkol jagung menjadi arang dan kemudian di campurkan beberapa bahan lain lalu dicetak menggunakan mesin dan menjadi briket tongkol jagung yang siap untuk di pasarkan. Berdasarkan latar belakang dapat diketahui bahwa ketersedian limbah tongkol jagung yang sangat melimpah saat musim panen jagung berlangsung. Limbah tersebut tidak dimanfaatkan dengan baik, biasanya limbah tongkol hanya dibakar oleh warga atau pemilik limbah tongkol jagung tersebut. Oleh karena itu dibutuhkan suatu alat atau mesin untuk dapat dioperasikan untuk membuat suatu produk lain dari limbah, yaitu proses pembuatan briket. Tujuan dari penelitian ini adalah membuat mesin press arang tongkol jagung menjadi briket dengan kapasitas $40 \mathrm{~kg}$.

\section{METODE}

Metode penelitian yang digunakan pada penelitian ini adalah perancangan produk. Tahapan-tahapan dalam perancangan alat dapat dilihat pada diagram alir berikut.

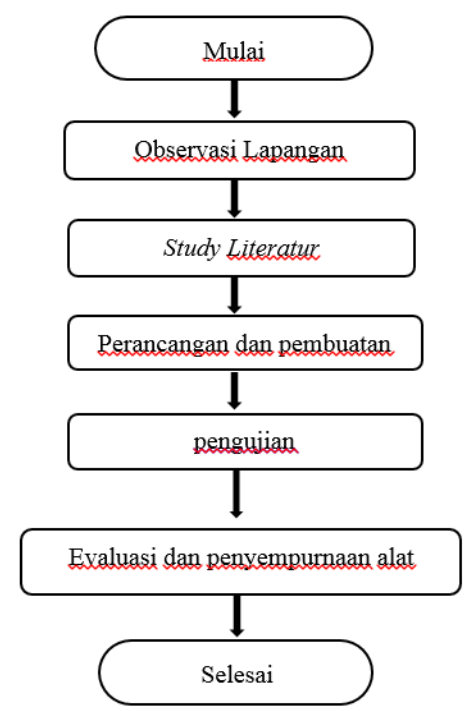

Gambar 1. Diagram Alir Perancangan Produk

Dalam pelaksanaannya, tahapan-tahapan yang dilakukan adalah sebagai berikut:

1. Observasi lapangan

Observasi lapangan dilakukan dengan cara mencari potensi yang dapat digunakan atau dikembangkan untuk memperoleh produk baru yang bisa dimanfaatkan kembali. Banyaknya limbah tongkol jagung yang dihasilkan petani di kawasan Kecamatan Ngunut Kabupaten Tulungagung merupakan suatu kerugian apabila tidak di konversikan kepada hal yang lebih efisien dan berguna. Maka di tinjau dari minimnya pengolahan limbah tongkol jagung, diperlukan pengembangan pada proses pengolahan limbah tongkol jagung untuk dijadikan bahan bakar alternativ dengan mengolahnya menjadi briket.

2. Studi literatur

Studi literatur dilakukan agar mendapatkan data-data tentang proses pengolahan limbah tongkol jagung yang selama ini dilakukan untuk mendapatkan dasar teori perancangan mesin press briket arang tongkol jagung.

3. Perancangan dan pembuatan

Proses perancangan dan pembuatan terdiri dari empat tahap yaitu desain awal produk, validasi desain, perbaikan desain, dan pembuatan produk.

4. Pengujian

Tahap pengujian meliputi Validasi data ini meliputi pemeriksaan bentuk fisik sesuai desain, uji coba pengoperasian produk, dan keamanan dan keselamatan kerja

5. Evaluasi dan penyempurnaan alat

Pada tahap ini perancangan dapat dievaluasi pada saat pengujian bertujuan agar digunakan sebagai penyempurnaan alat perancangan, sehingga alat perancangan dapat secara layak digunakan. 
Procedia of Engineering and Life Science Conference Vol. 1. No. 1 March 2021

Seminar Nasional \& Call Paper Fakultas Sains dan Teknologi (SENASAINS 1 ${ }^{\text {st) }}$

Universitas Muhammadiyah Sidoarjo

\section{Hasil dan Pembahasan}

\section{A. Desain alat}

Berikut disajikan hasil desain awal alat dan perbaikan desain pada Tabel 1.

Tabel 1. Desain Alat Sebelum dan Sesudah Validasi

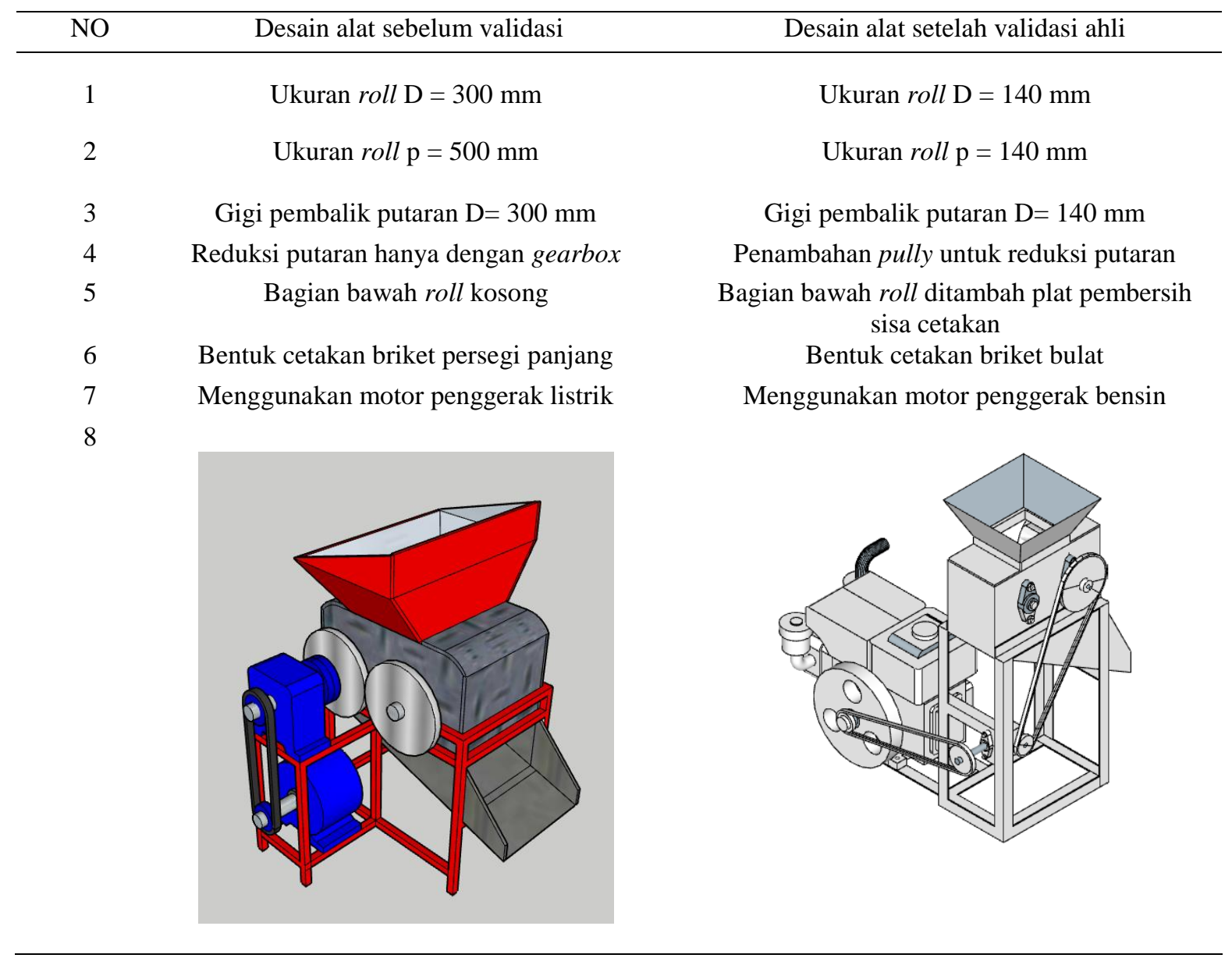

setelah melakukan validasi dan perbaikan desain diperoleh hasil spesifikasi perancangan mesin press arang tongkol jagung kapasitas $40 \mathrm{~kg} / \mathrm{jam}$ sebagai berikut

\begin{tabular}{ll}
\hline Kapasitas perencanaan & $40 \mathrm{~kg} / \mathrm{jam}$ \\
Penggerak & motor bensin \\
Dimensi rangka $(\mathrm{p} \times 1 \mathrm{x} \mathrm{t})$ & $690 \times 650 \times 950 \mathrm{~mm}$ \\
Putaran motor & $1000 \mathrm{rpm}$ \\
Putaran roll & $4,15 \mathrm{rpm}$ \\
Diameter pulley penggerak & 50 dan $130 \mathrm{~mm}$ \\
Perbandingan putaran gearbox & $1: 30$ putaran \\
Jumlah perbandingan gigi & $1: 3$ \\
Bahan rangka & Besi siku $3 \mathrm{~mm}$ \\
Dimensi rangka roll $(\mathrm{p} \times 1 \times \mathrm{t})$ & $300 \times 200 \times 200 \mathrm{~mm}$ \\
Tebal roll pencetak & Besi $4 \mathrm{~mm}$ \\
Diameter roll pencetak & $140 \mathrm{~mm}$ \\
Lebar roll pencetak & $140 \mathrm{~mm}$ \\
Diameter lubang pencetak & $35 \mathrm{~mm}$ \\
\hline
\end{tabular}




\begin{tabular}{ll}
\hline \hline Kedalaman lubang pencetak & $17 \mathrm{~mm}$ \\
Bearing & UCFL 205 \\
Panjang as & $290 \mathrm{dan} 350 \mathrm{~mm}$ \\
Diameter as & $25,4 \mathrm{~mm}$ \\
\hline
\end{tabular}

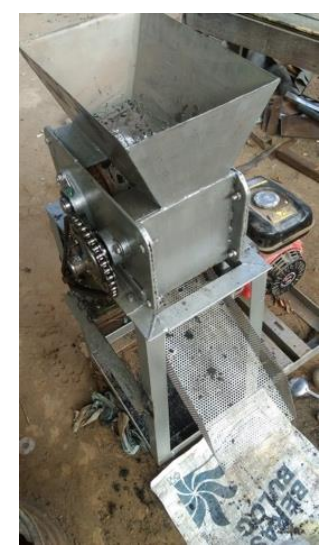

Gambar 2. Mesin Press Tongkol Jagung

\section{B. Uji coba alat}

Berikut merupakan komponen mesin press

1. Motor penggerak

Motor penggerak berfungsi sebagai penggerak utama putaran roll pada mesin press briket. Motor penggerak yang digunakan pada mesin press ini adalah motor bensin 1 Hp dengan putaran $1000 \mathrm{rpm}$.

2. Pulley

Pulley ini berfungsi untuk menstransmisikan daya putaran dari gearbox menuju roll pencetak. Rasio perbandingan diameter pully dari gearbox dan pully pada roll adalah 1:2 Untuk memperoleh putaran yang diinginkan maka diperoleh perhitungan sebagai berikut:

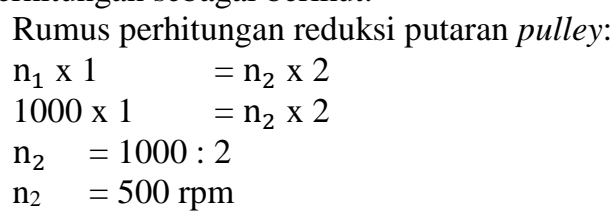

\section{Gearbox}

Gearbox ini berfungsi untuk meningkatan torsi dan mengurangi kecepatan motor yang akan memutar mesin press. Shaft dari motor akan terhubung ke salah satu ujung gearbox, melalui jajaran gear yang ada di dalam gearbox akan didapatkan torsi dan kecepatan yang diinginkan. Perbandingan putaran gearbox ini adalah $1: 30$. Untuk memperoleh putaran yang diperlukan maka diperoleh perhitungan sebagai berikut:

$$
\begin{array}{ll}
\mathrm{n}_{1} \times \mathrm{i} & =\mathrm{n}_{2} \times 30 \\
500 \times \mathrm{I} & =\mathrm{n}_{2} \times 30 \\
\mathrm{n}_{2}=500: & 30 \\
& \mathrm{n}_{2}=16,6 \mathrm{rpm}
\end{array}
$$

\section{V Belt}

$V$ belt ini berfungsi untuk mentransmisikan daya putaran dari poros satu ke poros yang lainnya. Seperti dari poros motor listrik ke poros gearbox, pully dan roll pencetak.

5. Gigi sprocket dana rantai

Gigi sprocket dan rantai ini berfungsi untuk meneruskan putaran dari gearbox menuju roll. Perbandingan putaran gear dari gearbox menuju gear roll adalah $1: 4$.

Rumus perhitungan reduksi putaran sprocket dan rante:

$$
\begin{array}{ll}
\mathrm{n}_{1} \times \mathrm{i} \quad=\mathrm{n}_{2} \times 2 \\
16,6 \times \mathrm{I}=\mathrm{n}_{2} \times 4 \\
\mathrm{n}_{2}=16,6: 4
\end{array}
$$




$$
\mathrm{n}_{2}=4,15 \mathrm{rpm}
$$

6. Gigi pembalik putaran

Gigi pembalik putaran ini berfungsi sebagai pembalik putaran dari salah satu roll agar berputar berlawanan untuk mengepress briket. Diameter gigi pembalik ini $250 \mathrm{~mm}$.

7. Roll cetakan

Roll cetakan ini berfungsi untuk mencetak briket dengan cara memasukkan hasil adonan briket kedalam roll yang berputar. Briket akan tertekan oleh kedua sisi roll dan akan masuk kedalam lubang pencetak dan akan keluar dengan sendirinya dalam bentuk seperti lubang cetakan. Ukuran diameter roll ini adalah $140 \mathrm{~mm}$ dan lebar roll $140 \mathrm{~mm}$. sedangkan lubang cetakan briket dengan diameter $35 \mathrm{~mm}$ dan kedalaman 1,7 $\mathrm{mm}$.

8. Rangka

Rangka ini berfungsi untuk menyokong keseluruhan dari mesin press briket arang tongkol jagung. Rangka yang digunakan menggunakan bahan besi kanal U, karena bahan ini lebih kuat untuk menyokong keseluruhan rangkaian mesin press.

9. Hopper

Hopper berfungsi sebagai penghantar. Hopper pada mesin press bagian atas berfungsi untuk mengarahkan adonan menuju roll pencetak, dengan ukuran panjang 350mm dan lebar $240 \mathrm{~mm}$. Sedangkan hopper bagian bawah berfungsi untuk mengarahkan hasil cetakan briket menuju mesin pengering atau oven, dengan ukuran panjang $660 \mathrm{~mm}$ dan lebar $200 \mathrm{~mm}$.

Hasil perancangan mesin press arang tongkol jagung menjadi briket kapasitas $40 \mathrm{~kg}$ akan dilakukan beberapa tahap uji coba yaitu, pemeriksaan bentuk fisik sesuai desain, pengoperasian, keamanan, dan uji coba pengepressan briket yang di hasilkan. Pemeriksaan bentuk fisik perancangan dimulai deri segi dimensi, standart penggunaan bahan, dan penggunaan alat pendukung dengan spesifikasi sesuai standard.

Tabel 4.2 Tabel Analisis Hasil Ujicoba

\begin{tabular}{ccccc}
\hline No & $\begin{array}{c}\text { Waktu } \\
\text { Percobaan }\end{array}$ & $\begin{array}{c}\text { Waktu } \\
(\text { menit })\end{array}$ & Hasil $(\mathrm{kg})$ & Hasil (kg/menit) \\
\hline 1 & $15.20-15.30$ & 10 & 35 & 3,5 \\
2 & $15.35-15.45$ & 10 & 37 & 3,7 \\
3 & $15.45-15.55$ & 10 & 37 & 3,7 \\
4 & $15.57-16.07$ & 10 & 36 & 3,6 \\
5 & $16.10-16.20$ & 10 & 38 & 3,8 \\
6 & $16.20-16.30$ & 10 & 39 & 3,9 \\
\hline \multicolumn{7}{c}{ Rata-rata } & 37 & 3,7 \\
\hline
\end{tabular}

$$
\begin{aligned}
& X=\frac{x i}{n} \\
& X=\frac{22,2}{6} \\
& X=3,7 \mathrm{~kg} / \text { menit }
\end{aligned}
$$

Keterangan:

$x i=$ hasil briket

$n=$ banyaknya pengulangan

jadi, rata rata mesin press mengasilkan $3,7 \mathrm{~kg} / \mathrm{mnt}$

Dari hasil uji coba perancangan mesin press arang tongkol jagung kapasitas $40 \mathrm{~kg}$ menjadi briket ini dalam waktu 10,7 menit dapat menyelesaikan $40 \mathrm{~kg}$ bahan dengan kecepatan putaran roll 4,15 rpm. Dengan hasil uji coba yang di lakukan pada perancangan ini dapat di katakan efektif sesuai kapasitas perancangan.

Berikut adalah gambar hasil cetakan briket arang tongkol jagung yang akan di keringkan pada mesin pengering atau oven. 


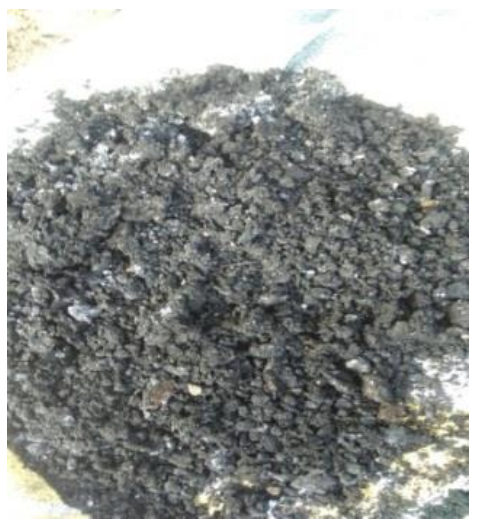

Gambar 3. Briket Sebelum Dicetak

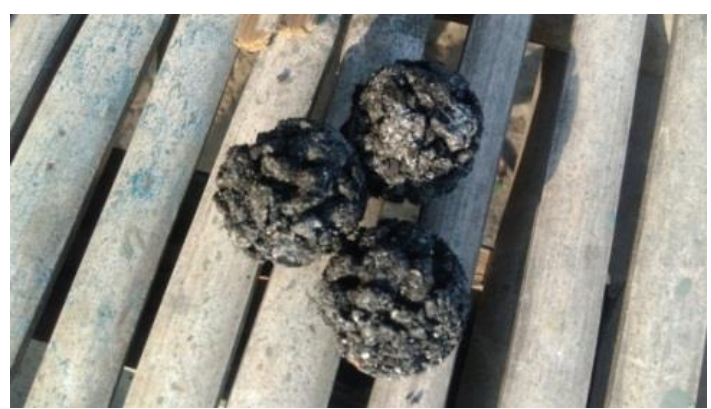

Gambar 4. Briket Setelah Dicetak

\section{KESIMPULAN}

Berdasarkan hasil penelitian yang dilakukan dapat disimpulkan bahwa mesin press arang tongkol jagung yan dibuat memiliki kapasitas $40 \mathrm{~kg} / \mathrm{jam}$. Mesin ini memiliki diameter lubang pencetak $35 \mathrm{~mm}$ dan kedalaman lubang pencetak $17 \mathrm{~mm}$. Kecepatan putaran roll yang dihasilkan mencapai 4,15 rpm. Dengan adanya mesin ini diharapkan bahwa limbah tongkol jagung yang dihasilkan oleh sektor pertanian dapat dimanfaatkan kembali yaitu menjadi briket.

\section{REFERENSI}

[1] M. D. Setyopambudi, "Analisa Karakteristik Mekanik Briket Dengan Variasi Ukuran Partikel Briket arang Limbah Serbuk Gergaji Kayu Sengon," Universitas Jember, 2015.

[2] I. Isa, "Briket Arang Dan Arang Aktif Dari Limbah Tongkol Jagung," Universitas Negeri Gorontalo, 2012.

[3] S. HALUTI, "PEMANFAATAN POTENSI LIMBAH TONGKOL JAGUNG SEBAGAI BIOETHANOL MELALUI PROSES FERMENTASI DIWILAYAH PROVINSI GORONTALO,” Jurnal Technopreneur, 2016.

[4] A. Ardinal, R. Wirni, and N. A. Haryati, "Pengaruh penambahan limbah tongkol jagung untuk pembuatan batu bata ringan," Jurnal Litbang Industri, 2020, doi: 10.24960/jli.v10i1.6180.39-45.

[5] S. E. Ariyanto and S. Slamet, "Teknologi Pengolahan Limbah Pertanian Tongkol Jagung untuk Mengatasi Masa Paceklik Pakan Ternak,” Dian Mas, 2014. 